\title{
A Research on Investment Behavior of Corporate and Individual Investors from Southern India
}

\author{
Ashish Dewan, R Gayatri, Rishi Dewan
}

\begin{abstract}
Current study aims to identify the factors affecting investment behavior of the corporate and individual investors, and also to make a comparative study of the investment behavior of both the corporate and individual investors from Southern India. The study was primarily based on the perception of the investors and the data was collected from 576 investors (304 individual investors and 272 corporate investors) from four major cities of South India namely; Bangalore, Hyderabad, Chennai and Visakhapatnam using questionnaire method. Researcher has identified total four factors which successfully represent the investment behavior of the corporate and individual investors. These factors are mainly; Investors related factors, Market or environment related factor, Investment related factors and Company specific factors. Further, it was found from the comparative analysis of the corporate and individual investors, that there is a significant difference in the investment behavior of the corporate and individual investors from Southern India.
\end{abstract}

Keywords - Investment Behavior, Corporate Investors, Individual Investors, Southern India, Investors related factors, Market or environment related factor, Investment related factors and Company specific factors.

\section{INTRODUCTION:}

Stock market is an enormous, unstable and entirely volatile hub where unfathomable investment transactions are carried out on quotidian basis. The recent years have witnessed the humongous transformations in the patterns of investments by the potential investors. There has been a drastic and pragmatic shift from the real estate or gold investment to the portfolio investment avenues such as shares, insurance, bonds, mutual funds, government securities and fixed deposits (Nofsinger and Richard, 2002). Even stock market has a market the crystal clear entrance of the women investors in the portfolio investment during last few years. The corporate culture and rise in the level of cognizance among the individuals or business firms to move ahead in the stock market investments due to several existing reasons. In fact, the avid readers across genders have sustained the zeal to make and secure their fortunes in the stock market investments due to the availability of a wide range of books being written by the top level investors like Warren Buffet etc. to motivate the individuals and reshape their ideology to act away from run of the mill practices. The investments are basically the commitments of

Revised Manuscript Received on April 12, 2019.

Ashish Dewan, Research Scholar, St.Peter's Institute of Higher Education and Research, Avadi, Tamil Nadu, Chennai.

Dr. R Gayatri, Professor, Department of Management Studies, St.Peter's Institute of Higher Education and Research, Avadi, Tamil Nadu, Chennai.

Dr. Rishi Dewan, Professor, Department of Management Studies, St.Peter's Institute of Higher Education and Research, Avadi, Tamil Nadu, Chennai. the capital or primary wealth by the multiple investors to buy financial assets or the instruments for reaping the profitable returns in terms of income, interest or appreciation or hike in the value of the particular financial assets.

Investment decisions undertaken by individuals are based on their attitudes, mindset or ideological set up which is based on the psychological strategy and their opinions in context to stock market investment conceptualize the investment behaviour. The entire framework or process of investment behavior encompasses the investors' investment judgments, their perceptions, prospects, analysis, procedures and review of procedures for the decision making that encapsulates mustering the information, defining and understanding the whole market, conducting research about the alternatives in the market, which could be fruitful in the near future and making investment decisions (Alfredo and Vicente, 2010). The investment decisions are made by the investors on the basis of their risk bearing ability, his perception about the risk, expectancy from the return and need. The decisions are generally based on the analysis of fundamental aspects, technical indices and the judgment on the part of investors (Jagongo and Mutswenje, 2014). Moreover, there are certain psychological root causes such as apprehensions of the investors, their avarice to have return in abundance and the wealth maximization by leaps and bounds as well as possibility of speculations in the highly volatile stock market, which might result in behaving with irrationality on some false chimeras (Warneryd, 2001; Evans, 2006; Gao and Schmidt, 2005). It is evident from the financial developments undertaken in the recent years that stock market is entirely associated with the attributes like risk associated with investment and instabilities on the practical and realistic turf, away from the rational approach of the investors (Rahman and Hunjra, 2012). They are deviated from the rigid and antiquated approach of financial investments while making investment decisions on the uncertain grounds.

There are distinctive echelons of investors right from individual or retail investors to the institutional or the corporate investors. Institutional or corporate investors are highly benchmark-oriented as they are able enough to make high-quality investment decisions. They have investment managers who take a bird eye view of the stock market indices and well acquainted with their responsibilities. The managers apply the financial and heuristics techniques while 
concocting the investment decisions for the corporations or the institutions. Moreover, the corporate investment decisions are made with the active engagement of the Board of Management they are the bigwigs in the domain of portfolio investment. On the other hand, the retail or individual investors are keen of making investments in the stock market out of their small fortunes on the basis of their judgment, rationality and quotidian knowledge of market conditions at their own level. Apart from this, the individual or institutional investors are different from each other on the basis of scale and boundaries of their investments in terms of overseas investments or confinement to the domestic industry.

Although, the investment decisions of both the investors are influenced by some intrinsic and extrinsic factors, but the factors that affect the decisions of both the investors are comparatively distinctive from each other. There is a difference in the investment psychology of the individual and the corporate investment in the stock market. The individual investors aim at maximizing their fortunes swiftly on the short term basis where as the institutional investors aim at long term sustenance withstanding the possible significant gauntlets in the highly dynamic and complex capital or stock market. The understanding of the stock market is incomplete without going through the core aspects of different levels of investment decisions undertaken by the investors. Hence, it becomes substantial to have a sneak peek of the factors, which act as the foundation for all the investment decisions in the stock market.

After explaining the need of the current study, a detailed review of existing literature has been given in subsequent section along with the research gaps, following which the objectives of the study and research methodology has been described by researcher. Findings and discussion section comprises the results of the study, along with interpretation, followed by a brief conclusion of the study. At last the limitations and future scope of the study, and practical implications of the study has been included.

\section{REVIEW OF LITERATURE:}

The investment industry has proliferated by leaps and bounds across the last few years. There are many National as well as International companies, which are coming up with a wide range of products to enable the investors making investment decisions. Many studies have been conducted to elucidate the prominent factors that influence the psychology of potential investors across different strata and gender in the economy. These factors basically shape the investment criterion and trends in the securities market. Besides this, the studies also highlight the role played by the financial advisors, distributors and brokers in shaping the mindset of investors. Moreover, the studies have also suggested certain effective measures to build the trust and influence the ideology of the customers to enable them to make appropriate decisions. There are many recommendations made by the researchers, which are necessary to be acknowledged by the investors to polish their knowledge regarding the financial economy.

Mak and Lp (2017) analyzed the financial investment behavior of investors and found that sociological, psychological and demographic factors like income level, educational level, gender, marital status and investment experience, influenced the investors' behaviors. Financial service providers must make suitable strategic plans to understand the investment approach of various interested investors. Jagongo and Mutswenje (2014) revealed that reputation of the firm, its status in the industry, price per share, dividend expected by the investors, expected corporate earnings, conditions and profit of statement, impact of the investments on the economy had been the major factors, which influenced the individual investor's decision regarding investment in the particular firm. Anitha and Bhargavi (2014) revealed the different trends and perceptions regarding investment decisions across ages and genders. Female and old age investors were found having less risk preferences and reluctance towards taking risky decisions. It was also found that males and young investors were active in taking diverse decisions regarding investment in stock market. Phan and Zhou (2014) explored that individual's own attitude towards investment, investment norms, perceived behavioral control and some psychological factors like collective or herd behavior, optimistic approach, psychology associated with risk as the imperative stimulators that influence the individual's intention towards investment. Palanivelu and Chandrakumar (2013) revealed that age of investors, their level of education as well as awareness about the contemporary investment patterns and income level were found to be substantial for influencing the investment intents of working class. The study also emphasized that Stock Broking firms should conduct awareness programs to provide knowledge to the potential investors regarding new ventures. Deene and Pathi (2013) assessed various motivational agents and investment strategies related to corporate investment. The study highlighted that risk and return associated with the investment venture, share prices in the market, services of financial advisors, media coverage, quality of management and timings of investment as the major factors that influence the investor's decisions. Walia and Kirana (2009) explored the psychology of 525 investors regarding their investment intentions towards commodity market in India and found that low risk, asymmetrical information, high level of returns and adequate knowledge regarding objectives as the major factors, which influenced the investment behavior of the individuals. Virani (2013) determined that income of the respondents was the major factor that influences their investment decisions. Bank deposits were found to be the imperative segment of investment to fulfill the several needs like education and marriage of their children as well as safety and security after retirement. Sireesha and Laxmi (2013) ascertain the effect of demographic factors on the investment avenues chosen by investors. The research stated gender, age and friends as the major factors to influence the investment intentions of the respondents. The investors were also found as conservative and lesser concerned regarding the proliferation of money and liquidity to get the benefits for long. Bashir et al., (2013) examined the association between demographic constraints and the investment 
preferences among the 120 finance teachers and bankers of Gujarat and Sialkot, India. The study depicted the females as more risk averse as compare to male folks. The young and educated individuals were found to be positive as well as reluctant towards the risk investments due to limited resources, improper knowledge of investment trends and lack of adequate investment opportunities in the economy. Negative association between non-conducive economic environment and culture with gambling was also found while making investment decisions. Jayaraj, (2013) identified the prominent factors that influence the psychology of individual investor's investment intents. The study highlighted the presence of some psychological axes such as conservatism, diligence and remorse abhorrent fall as well as some behavior axes in terms of low level of confidence and prudence. Dhar and Dey (2012) conducted a study with 82 individuals to ascertain the effect of psychological perceptions on their investment patterns. The study highlighted that the optimistic individuals and male investors were in favor of long term investments. The trust was found as the major factor, which influenced the investment intentions of individuals. Murithi et al., (2012) investigated the investment behavior of 100 individuals in various investment avenues in India. The study depicted the investment in gold, land, Life insurance and Mutual funds as the foremost priority among the female investors as the market dominators. The research also found the expectation of more income and less risk on the part of big investors as well. Moreover, the investors were found well aware about the risk and return from the portfolio investments. Chandra and Kumar (2012) revealed the presence of asymmetrical pattern of information, which influences the investment intentions of individual investors to a large extent. The investors were found to make industrious access to the gains and losses while making the investment decisions. Psychological heuristics had been found as the significant constraint to affect the mentality of investors. It was also stated that the easily adjustable pieces of information had been preferred by the majority of respondents for making better investment decisions. Sultana and Paradhasaradhi
(2012) analyzed the determinants of investment decisions of Indian equity investors. The researchers depicted perceptions of particular investment brand, individual eccentric, wealth maximization, risk minimization, social responsibility, influence of media and Government, financial expectations from distinctive avenues, economic expectations from the investment avenues and recommendations from other investors as the major factors that influence the investment behaviors of investors. Jain and Jain (2012) elucidated bank deposits as the major avenue of investment preferred by the respondents. Savings were preferred by the respondents to meet the diverse needs related to wellbeing of their children and safety as well as security of employees after their retirement. Chakraborty (2012) analyzed the saving goal, investment patterns and preferences among the women and men investors. The study foregrounded that many demographic factors like age, occupation and income echelons of investors influenced the saving objective of the investors. Women investors were found to be risk averse but tend to save more as compare to the male investors along with the hike in their level of income. Kousalya and Gurusamy (2012) analyzed the perceptions of women investors regarding the investment avenues in the Indian securities market and the factors that influence their investment decisions. The study observed the low level of awareness among the women investors with regard to investment avenues despite their educational status. Besides, the study did not find any magnificent association between the age of women investors and their level of awareness regarding the numerous ventures of investment available in the market. Chaturvedi and Khare (2012) examined the awareness regarding the investment in securities across genders in India. The research did not observe any significant relationship between the age, gender of investor and their level of sentience among the investors with regard to investment channels and avenues available in the market. A summarized table of various studies conducted by the researchers from different countries to analyze the behavior of the investors, and to identify the factors affecting investment behavior of the investors.

Table 1: Summary of Factors influencing Investment Decisions of the investors

\begin{tabular}{|l|l|l|l|l|}
\hline S.N. & Citation & $\begin{array}{l}\text { Area of the } \\
\text { study }\end{array}$ & $\begin{array}{l}\text { Type of } \\
\text { Investor }\end{array}$ & Factors affecting investment Behavior \\
\hline $\mathbf{1}$ & $\begin{array}{l}\text { Mak and Lp } \\
(2017)\end{array}$ & $\begin{array}{l}\text { Mainland China } \\
\text { and Hong Kong }\end{array}$ & $\begin{array}{l}\text { Individual } \\
\text { Investors }\end{array}$ & $\begin{array}{l}\text { Sociological, psychological and demographic factors } \\
\text { like income level, educational level, gender, marital } \\
\text { status and investment experience }\end{array}$ \\
\hline $\mathbf{2}$ & $\begin{array}{l}\text { Jagongo and } \\
\text { Mutswenje (2014) }\end{array}$ & Nairobi & $\begin{array}{l}\text { Individual } \\
\text { investors }\end{array}$ & $\begin{array}{l}\text { Reputation of the firm, its status in the industry, price } \\
\text { per share, dividend expected by the investors, expected } \\
\text { corporate earnings, conditions and profit of statement, } \\
\text { impact of the investments on the economy. }\end{array}$ \\
\hline $\mathbf{3}$ & $\begin{array}{l}\text { Anitha and } \\
\text { Bhargavi (2014) }\end{array}$ & India & Retail Investors & Demographic factors: Age and gender \\
\hline $\mathbf{4}$ & $\begin{array}{l}\text { Phan and Zhou } \\
\text { (2014) }\end{array}$ & Vietnam & $\begin{array}{l}\text { Corporate } \\
\text { Investors }\end{array}$ & $\begin{array}{l}\text { Investment norms, perceived behavioral control and } \\
\text { psychological factors like collective or herd behavior, } \\
\text { optimistic approach, psychology associated with risk }\end{array}$ \\
\hline
\end{tabular}




\begin{tabular}{|c|c|c|c|c|}
\hline 5 & $\begin{array}{l}\text { Palanivelu and } \\
\text { Chandrakumar } \\
(2013)\end{array}$ & $\begin{array}{l}\text { Namakkal Taluk, } \\
\text { Tamil Nadu }\end{array}$ & $\begin{array}{l}\text { Salaried class } \\
\text { investors }\end{array}$ & $\begin{array}{l}\text { Age of investors, level of education and awareness } \\
\text { about the contemporary investment patterns and } \\
\text { income level }\end{array}$ \\
\hline 6 & $\begin{array}{l}\text { Sultana and } \\
\text { Paradhasaradhi } \\
(2012\end{array}$ & India & $\begin{array}{l}\text { Equity } \\
\text { investors }\end{array}$ & $\begin{array}{l}\text { Investment brand, individual eccentric, wealth } \\
\text { maximization, risk minimization, social responsibility, } \\
\text { influence of media and Government, financial } \\
\text { expectations, economic expectations and } \\
\text { recommendations from other investors }\end{array}$ \\
\hline 7 & $\begin{array}{l}\text { Kousalya and } \\
\text { Gurusamy (2012) }\end{array}$ & India & $\begin{array}{l}\text { Women } \\
\text { Investors }\end{array}$ & Age, education and awareness level of investors \\
\hline 8 & $\begin{array}{l}\text { Geetha and } \\
\text { Ramesh (2011) }\end{array}$ & $\begin{array}{l}\text { Kurumbalur } \\
\text { Town, India }\end{array}$ & $\begin{array}{l}\text { Individual } \\
\text { Investors }\end{array}$ & Income level of the investors \\
\hline 9 & $\begin{array}{l}\text { Panahian et al., } \\
(2011)\end{array}$ & Tehran & $\begin{array}{l}\text { Corporate } \\
\text { investors }\end{array}$ & $\begin{array}{l}\text { Corporate aspects, broad structure, performance of } \\
\text { companies in the market, transparency in financial } \\
\text { position of the firms, availability of controlling } \\
\text { measures, structure of ownership }\end{array}$ \\
\hline 10 & $\begin{array}{l}\text { Hare and Fofie } \\
(2009)\end{array}$ & Ghana & Policymakers & Market conditions, and economic environment \\
\hline 11 & Collard (2009) & $\begin{array}{l}\text { UK, US, Sweden } \\
\text { and Australia }\end{array}$ & $\begin{array}{l}\text { Pensioner } \\
\text { investors }\end{array}$ & Financial education and effective communication \\
\hline 12 & Naimy (2008) & New York & $\begin{array}{l}\text { Equity } \\
\text { Investors }\end{array}$ & Awareness level of investors, \\
\hline 13 & $\begin{array}{l}\text { Donnor and } \\
\text { Oxenstierna (2007) }\end{array}$ & Sweden & $\begin{array}{l}\text { Corporate } \\
\text { Investors }\end{array}$ & $\begin{array}{l}\text { Reputation of the financial products and their } \\
\text { availability in the securities market, fund specific traits } \\
\text { and goodwill of the company }\end{array}$ \\
\hline 14 & $\begin{array}{l}\text { Athanasious et al., } \\
(2005)\end{array}$ & Greece & $\begin{array}{l}\text { Mutual funds } \\
\text { holders }\end{array}$ & $\begin{array}{l}\text { Risk and return associated with the funds and } \\
\text { securities }\end{array}$ \\
\hline 15 & $\mathrm{Ng}$ and $\mathrm{Wu}(2005)$ & Shanghai & $\begin{array}{l}\text { Middle level } \\
\text { investors }\end{array}$ & $\begin{array}{l}\text { Less market prices, high level of return, low level of } \\
\text { risk, high betas, small market capitalization and last } \\
\text { year's low performance stocks }\end{array}$ \\
\hline
\end{tabular}

\section{RESEARCH GAPS:}

There is a lack of studies conducted where the behavior of corporate investors has been measured, corporate investors are the major investors of the stock market and can easily influence the trend of stock prices. Hence, it is important to conduct the study on measuring the behavior of corporate investors. The literature does not contribute much towards the comparative study of individual and corporate investors. As there is a difference in these two categories of investors hence, there is a need to compare the factors which affect the behavior of individual and corporate investors. The studies are mainly limited to the investors of north India, or Maharashtra, South Indian investors' behavior has not been studied much.

\section{OBJECTIVES:}

1. To identify the factors affecting investment behavior of corporate and individual investors from Southern India.

2. To compare the investment behavior of corporate and individual investors from Southern India.

\section{RESEARCH METHODOLOGY:}

Primary data has been used to measure the investors' opinions while secondary data has been used for review of literature, and for getting an in depth understanding of the subject matter of the research. Primary data has been collected personally by face to face interaction with the investors. The period of the data collection was from October 2019 to March 2019. Current study based on the data collected from the investors of Southern India. Hence, all the investors whosoever have invested in any kind of market security, shares, debentures, etc. were considered as the population of the study. As per the report of Census 2011, there are four major cities of Southern India namely; Bangalore, Hyderabad, Chennai and Visakhapatnam; which encompasses the highest population and which keeps a place in top 20 largest cities of India. Hence, all these four major cities have been taken as sample in the study, from where the data has been collected in the study. As the population of the study is infinite in nature, hence it is solely depends on the discretion of the researcher that what will be sample size of the study. The higher the sample size higher will be the normality in the data and chances of generalized results also get increased. Keeping in view the law of large data, researcher has collected data from 200 investors comprises 100 corporate and 100 individual investors from each of the four cities. Hence, total number of investors contacted for the data collection were 800 in total out of which only 576 completely filled up questionnaire were received from the investors. Response 
rate of the survey was 72 percent of which 68 percent response rate was recorded for corporate investors and 76 percent response rate was recorded for the individual investors. Researcher has used snowball sampling technique for the data collection. Few respondent of the study were identified using personal references and then through the reference of the respondents further respondents were approached. While the selection of the cities was done systematically based on the population size. In current study, researcher has used correlation analysis to measure the relationship between different factors which affect the investment behavior of the investors from Southern India. In order to categorize all the factors under various heads or called factors this method has been used which is popularly known as data reduction method. In order to identify the factors affecting investment behavior of corporate and individual investors from Southern India. Following are the factors identified using exploratory factor analysis in the current study which have reduced 40 statements under four major factors representing investment behavior:

Factor 1: Investors related factors (14 Statements)

Factor 2: Market or environment related factor (10 Statements)

Factor 3: Investment related factors (9 Statements)

Factor 4: Company specific factors (7 Statements)

Hypothesis: Following hypothesis has been tested during current study.

Null Hypothesis 1: There is no significant difference in the investment behavior of corporate and individual investors from Southern India.

Null Hypothesis 2: There is no significant difference in the factors investment behavior of corporate and individual investors from Southern India.

Independent sample t-test will be used to measure the difference in the investment behavior of two groups of investors' i.e. corporate investors and individual investors. Moreover, the difference in the factors affecting the investment behavior of two groups of investors will also be measured using independent sample t-test. In current study researcher has used exploratory factor analysis to reduce the number of variables taken in the study which represent the investment behavior of the corporate and individual investors.

\section{RESULTS AND DISCUSSIONS:}

Reliability has been measured for the complete questionnaire using Cronbach Alpha method which is most accepted method by researchers. The value of Cronbach alpha was found to be 0.821 , which was above 0.70 which is acceptable, hence the questionnaire was found to be reliable. KMO and Bartletts' Test was performed to test the adequacy of the data and suitability of th data before applying factor analysis. The results of the KMO test showed that the test value is 0.953 , which is almost equal to one and hence sample size of the study was found to be adequate or large enough to apply factor analysis. Further, the value of Chi-square test was found to be 32881.22 at a p-value of 0.000 , which indicates that the Batlett's test for sphericity is also significant and data can be used for the factor analysis. As per the results of Principal Component Method, total four factors have been extracted from which successfully represent the investment behavior of the corporate and individual investors from Southern India. These four factors counted total 81.728 percent of the variation in the investment behavior while rest of the 18 percent of the variation can be assigned to other factors. The first factor explains the 28.203 percent of the variation, second factor explain 19.871 percent of the variation, while third and fourth factor explain 18.943 and 14.711 percent of variation in the investment behavior respectively.

\section{Table 1: Results of EFA using PCA method with Varimax rotation method}

\begin{tabular}{|l|l|l|}
\hline S. No. & $\begin{array}{l}\text { Factor 1 (Investors related Factors = 14 statements, Mean Value = 3.21, Variation Explained } \\
28.203 \% \text { Alpha Value = 0.869) }\end{array}$ & $\begin{array}{l}\text { Factor } \\
\text { Loadings }\end{array}$ \\
\hline 1 & Risk perceptions of the investors & .897 \\
\hline 2 & Goals or purpose of investors related to investment & .885 \\
\hline 3 & Skills and abilities of the investors/fund managers & .883 \\
\hline 4 & Influence of friends or colleagues & .882 \\
\hline 5 & Protection to investors & .880 \\
\hline 6 & Risk taking behavior of the investors & .872 \\
\hline 7 & Up to date information about market & .869 \\
\hline 8 & Consumption level of investors & .868 \\
\hline 9 & Availability of unused funds & .865 \\
\hline 10 & Financial conditions of the investors & .863 \\
\hline 11 & Individual needs of the investors & .862 \\
\hline 12 & Personal expectations of the investors & .858 \\
\hline 13 & Knowledge of the investors /fund managers about stock market & .845 \\
\hline 14 & Investors saving pattern & .844 \\
\hline Factor & (Market and ext & \\
\hline
\end{tabular}

Factor 2 (Market and external environment Factors $=10$ statements, Mean Value $=3.13$, Variation Explained $=19.871 \%$ Alpha Value $=0.855)$ 


\begin{tabular}{|l|l|l|}
\hline 15 & Safety norms of SEBI for investors & .889 \\
\hline 16 & New Government schemes related to the investment & .874 \\
\hline 17 & Stock market volatility & .868 \\
\hline 18 & Technological innovations in the industry & .852 \\
\hline 19 & Political conditions of the country & .849 \\
\hline 20 & Rise or down of foreign markets & .849 \\
\hline 21 & Instability of the industry or sector & .848 \\
\hline 22 & Recession in the market & .843 \\
\hline 23 & Foreign institutional investment & .839 \\
\hline 24 & Economic condition of the country & .827 \\
\hline Factor 3 (Investment Factors = statements, Mean Value =3.22, Variation Explained = 18.943\% Alpha Value $=0.812)$ \\
\hline 25 & Liquidity or the maturity period & .931 \\
\hline 26 & Lock in period & .918 \\
\hline 27 & Risk associated with the investment option & .916 \\
\hline 28 & Tax exemption or reduction in tax liability & .913 \\
\hline 29 & Previous years return on investment or growth in ROI & .913 \\
\hline 30 & Future growth predictability & .868 \\
\hline 31 & Risk of losing principal amount & .863 \\
\hline 32 & Variety of option for investment & .849 \\
\hline 33 & Expected Rate of return & .849 \\
\hline Factor 4 (Company specific Factors = 7 statements, Mean Value = 2.77, Variation Explained = 14.711\% Alpha Value $=$ \\
$0.725)$ & & \\
\hline 34 & Future or vision or mission of the company & .917 \\
\hline 35 & Previous years dividend policies & .906 \\
\hline 36 & Leadership or management of the company & .894 \\
\hline 37 & Future growth projects before company & .871 \\
\hline 38 & Financial stability of the company & .867 \\
\hline 39 & Reputation of the company issuing stocks/ securities & .854 \\
\hline 40 & Corporate image of the company & .852 \\
\hline & & \\
\hline
\end{tabular}

All the statements whose factor loadings was found above 0.40, after applying Varimax Rotation method, were retained in the final solution. Based on the factor loadings, researcher has extracted four factors which can explain the investment behavior. These factors are mainly; Investors related factors consisting total 14 Statements, Market or environment related factor consisting 10 Statements, Investment related factors consisting 9 Statements and Company specific factors consisting 7 Statements. Investment behavior of the corporate and individual investors got affected by mainly these four factors, and these factors affects their decision to make investment in any security.

Null Hypothesis 1: There is no significant difference in the investment behavior of corporate and individual investors from Southern India.

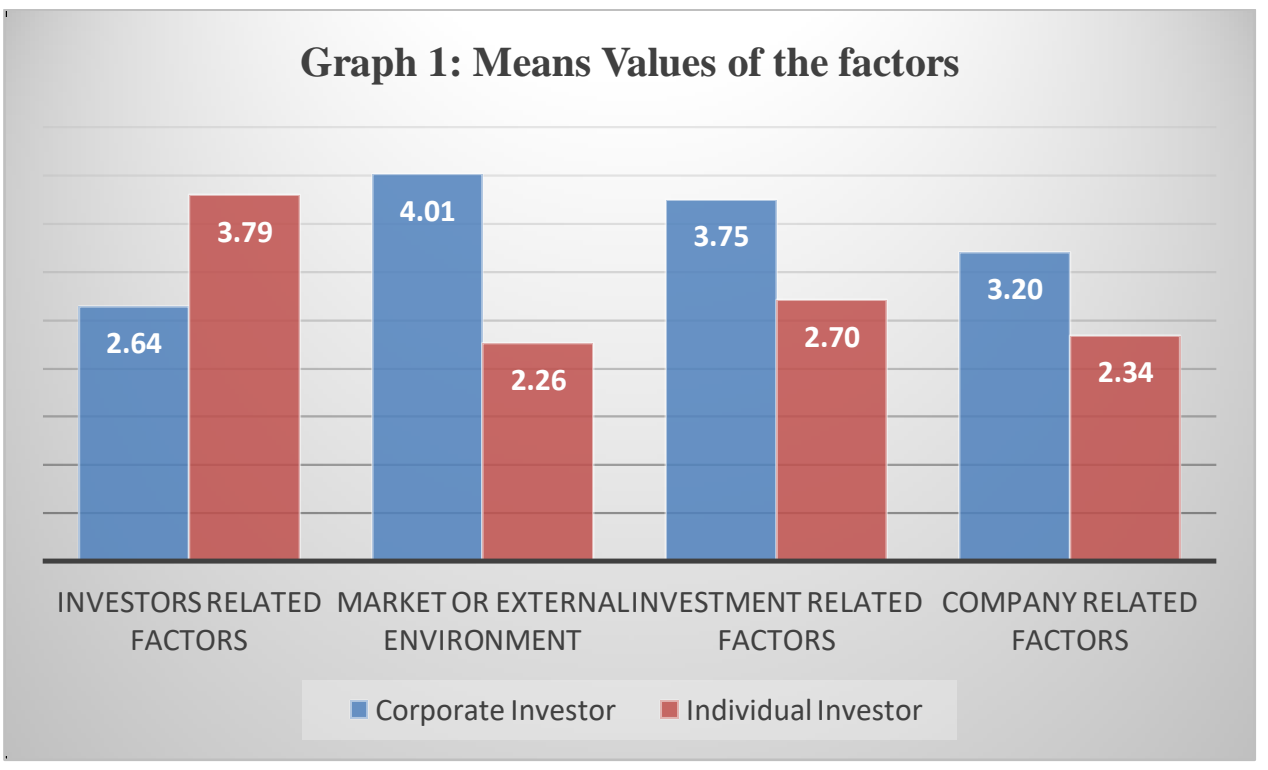


The comparison of mean values of investment behavior of corporate and individual Investors, for all the four factors revealed that the investment behavior of the corporate Investors get affected by market or external environment related factors, investment related factors and company related factors. But of these four factors the major factor which plays an important role while corporate Investors take any decision get affected by the market or external environment related factors. Similarly; the investment behavior of the individual Investor get affected by the investor related factors mainly. Rest of the three factors are important but not as much as for the Corporate Investors. Null Hypothesis got rejected in the study which states that there is no significant difference in the investment behavior of corporate and individual investors from Southern India. While there is a significant difference in the investment behavior of the two different type of investors.

Null Hypothesis 2: There is no significant difference in the factors investment behavior of corporate and Corporate Investors from Southern India.

Table 2: Results of Independent Sample t-test

\begin{tabular}{|l|l|l|l|l|l|l|}
\hline \multirow{2}{*}{ Factors } & \multicolumn{2}{|l|}{$\begin{array}{l}\text { Corporate Investor } \\
(\mathrm{N}=272)\end{array}$} & \multicolumn{2}{l|}{$\begin{array}{l}\text { Individual Investor } \\
(\mathrm{N}=304)\end{array}$} & $\begin{array}{l}\text { t-value } \\
(\mathrm{df}=574)\end{array}$ & $\begin{array}{l}\text { p-value } \\
\text { (99\% level of } \\
\text { confidence })\end{array}$ \\
\cline { 2 - 7 } & Mean & Std. Dev & Mean & Std. Dev & & .000 \\
\hline $\begin{array}{l}\text { Investors related } \\
\text { factors }\end{array}$ & 2.6363 & 1.02160 & 3.7919 & .77425 & -15.392 & .000 \\
\hline $\begin{array}{l}\text { Market or external } \\
\text { environment }\end{array}$ & 4.0096 & .47106 & 2.2589 & 1.01154 & 26.120 & .000 \\
\hline $\begin{array}{l}\text { Investment related } \\
\text { factors }\end{array}$ & 3.7451 & .91378 & 2.7039 & .70388 & 15.404 & .000 \\
\hline $\begin{array}{l}\text { Company related } \\
\text { factors }\end{array}$ & 3.1994 & .75993 & 2.3368 & .82703 & 12.984 & \\
\hline
\end{tabular}

The mean value of Corporate Investors for the 'investment related factors' was found to be 2.63, which is less than the mean value of the Individual Investors, hence it can be said that the Individual Investors behavior mainly get affected by the investors related factors. Further the t-value corresponding to the investment related factor was found to be -15.392 , at a p-value of 0.000 , which indicates that there is significant difference in the investment behavior of the corporate and Individual Investors, based on investment related factors.

The mean value of Corporate Investors for the 'Market or external environment' was found to be 4.00 , which is more than the mean value of the Individual Investors, hence it can be said that the corporate Investors behavior mainly get affected by the Market or external environment. Further the t-value corresponding to the investment related factor was found to be 26.120 , at a pvalue of 0.000 , which indicates that there is significant difference in the investment behavior of the corporate and Individual Investors, based on Market or external environment.

The mean value of Corporate Investors for the 'investment related factors' was found to be 3.74, which is more than the mean value of the Individual Investors, hence it can be said that the corporate Investors behavior mainly get affected by the Investment related factors. Further the t-value corresponding to the investment related factor was found to be 15.404 , at a p-value of 0.000 , which indicates that there is significant difference in the investment behavior of the corporate and Individual Investors, based on investment related factors.

The mean value of Corporate Investors for the 'Company related factors' was found to be 3.19 , which is more than the mean value of the Individual Investors, hence it can be said that the corporate Investors behavior mainly get affected by the investors related factors.
Further the t-value corresponding to the investment related factor was found to be 12.984 at a p-value of 0.000 , which indicates that there is significant difference in the investment behavior of the corporate and Individual Investors, based on investment related factors.

Hence, overall it can be said that there is a significant difference in the investment behavior of the corporate and Individual Investors, Individual Investors focus mainly on the factors related to themselves, such as their knowledge and skills, investment goals, savings and consumption pattern, financial needs, risk perception, amount of unused funds, and the financial condition of the investor. An individual investor before making any investment first try to get first-hand knowledge about the various investment options as per the funds they have, the maturity period/lock in period, return on investment, and the security of the funds. Sometimes the investment decisions of the individual get affected by the influence of the friends or family members, or relatives. Individuals take the feedback from their friends or relatives and then make investment in the particular security. Further, the risk taking capacity of the individual plays an important role in the investment behavior of the individual investors, as per their needs and or financial goals, their risk taking behavior also get change. Hence, if we look the investment behavior of the individual investors it completely different from the investment behavior of the corporate investors. Corporate behavior mainly focus on the market or external environment, they don't set short term financial goals but they invest for getting higher returns. Their amount of funds is larger than the funds available with an individuals, accordingly their risk

Blue Eyes Intelligence Engineering

\& Sciences Publication 
taking capacity also vary from that of individual investors. They take more interest in knowing the market conditions, economic conditions, as they mainly invest in the growth oriented funds, or the shares or securities instead of debt or balanced funds. Moreover, their always make the portfolio, as they have number of different kind of securities, which individual do not make as they don't have that much amount of funds. For corporate investors it is required to keep an up to date information about the company, its financial stability, dividend policy, share prices, last year's financial positions in order to keep the portfolio updated as per the market conditions. This is the main reason that corporate investors give more importance to the company specific factors, while the importance of the investment related factors that is almost equal for the corporate and individual investors. Both the investors look in to the risk, return, maturity period, lock in period, and tax exemption features of the investment. In terms of information sources, corporate investors have all resources to collect the information about the market, about the company and they can even in such capacity where they can easily afford the financial experts or portfolio or fund managers to manager their funds, while this is difficult for the individual investors, to have in depth knowledge of the market, whose full time profession is not related to the financial markets. Further, the lack of funds or the limited amount of funds make them unable to hire professional experts for the management of the funds or to acquire the market related knowledge. Even the type of investment options selected by corporate investors and the individual investors also vary, due to the risk bearing capacity of both the parties. Individual investors mostly make investment for the purpose of the future of their own, retirement, and purchase of house or property, marriage, education or simply to make utilization of the unused funds for future contingencies. There is a difference in the financial goals of both the corporate and individual investors hence, the investment options also varies among the investors.

The major difference in the corporate and the individual investors is based on the finances available with the investors for the investment purpose, difference in their financial goals or needs, difference in their knowledge and skills related to the market, risk perception of the investors, and the financial expertise of the both type of investors.

\section{CONCLUSION:}

Current study mainly aims to identify the factor which can have a bearing on the investment behavior, researcher has extracted total four factors which successfully represent the investment behavior of the corporate and individual investors. These factors are mainly; Investors related factors, Market or environment related factor, Investment related factors and Company specific factors. Further, from the comparative analysis of the investment behavior of the corporate and individual investors it got clear that corporate investors are more interested in getting knowledge about the market, external environment, rules of SEBI, and the internal information of the company issuing securities, such as; the profitability of the company, financial stability, liquidity position, dividend policy, last year's profits and other financial ratios. While investment behavior of the individual investors got affected by their personal factors related to the investors such as; level of knowledge or skills, saving pattern, consumption pattern, financial goals, influence of friends or relatives, risk perception, and the unused amount of funds with the investors. Apart from this, the investment related factors is almost equally important for both the corporate and individual investors.

Limitations and future scope: The scope of the current study is limited to the corporate and individual investors, of southern India, it can be extended to whole India or the other a state wise comparative study of the investment behavior of the investors. The study do not look into the demographic profile of the investors, which can have a major impact on the investment behavior. In future studies, demographic variables can be studied as the moderating variables, which can affect the investment behavior of different types of investors. Current study has not studied the preferences of the corporate and individual investors related to the investment options, which is also an important area to understand the behavior of both the type of investors in detail.

Practical Implications: Current study highlighted the factors affecting the investment behavior of the corporate and individual investors. The findings of the study can be beneficial for the financial institutions selling investment products to the corporate and individual investors. As they can equip themselves with the knowledge what is important for the corporate and individuals investors while making investment decisions, and they need to focus on those factors only for selling their products. Further, there is a need to understand by the marketing department of the financial products, that there should be different strategies to be planned and executed for capturing corporate and individual investors, as their financial goals, financial knowledge, financial capacity, risk capacity differs hence marketing strategies should also be different for both type of investors.

\section{REFERENCES}

1. Alferado Martin Oliver and Salas F. Vinvente (2010), "IT Investment and Intangibles: Evidences from Banks", SSRN Working Paper Series, pp. 20-47.

2. Anitha, D and Bhargavi, Phani (2014), "Investor's Perception Towards Investment", Global Journal of Finance and Management, Vol. 6, No. 2, 2014, pp. 185190.

3. Athanasious G. Noulas, John A. Papanastasiou, John Lazaridis (2005), "Performance of Mutual Funds", Managerial Finance, Vol. 31, Issue 2, pp. 100-112.

4. Bashir, T., Ahmed, H. R., Jahangir, S., Zaigam, S., Saeed, H., \& Shafi, S. (2013), "Investment preferences and risk level: Behavior of salaried individuals. IOSR Journal of Business and Management, Vol. 10, Issue 1, pp. 68-78.

5. Chandra, Abhijeet and Kumar, Ravinder (2011), "Determinants of Individual Investor Behavior: An Orthogonal Linear Transformation Approach", MPRA, Paper No. 29722. 
6. Chaturvedi, Meenakshi and Khare, Shruti. (2013), "Study of Saving Pattern and Investment Preferences of Individual Household in India", International Journal of Research in Commerce \& Management, Vol. 3, Issue 5, pp. 115-120.

7. Chakraborty, Suman (2012), "A Study of Saving and Investment Behavior of Individual Households - An Empirical Evidence from Orissa", TIJ's Research Journal of Economics, Vol. 2, pp. 12-19.

8. Collard, Sharon (2009), "Individual Investment Behavior: A Brief Review of Research", Final Report, January 2009, pp. 1-22.

9. Dhar, Pranam and Dey, Bishwarup. (2013), "Impact of Individual's Psychology in Their Investment Pattern: An Empirical Inquest in Indian Context", Business Spectrum", Vol. 1, Issue 3, pp. 15-22.

10. Deene, Shivakumar and Pathi,Satyanarayan, (2013), "Investment strategies and motivational factors among small investors: a study with special reference to Karnataka state", International Journal of Management, Vol. 4, Issue 4, pp. 34-38.

11. Donnor and Oxenstierna (2007), "The Factors that Investors Value when Choosing Mutual Funds: Implications from a Market Dominated by Four Banks", Applied Financial Economics, Vol. 11, pp. 457- 466.

12. Evans, D.A. (2006), "Subject Perceptions of Confidence And Predictive Validity In Financial Cues", Journal of behavioral Finance, Vol. 7, Issue 1, 2006, pp. 12-28.

13. Geetha, N. and Ramesh, M. (2011), "A Study on People's Preferences in Investment Behavior", IJEMR, Vol. 1, Issue 6, pp. 1-10.

14. Gao, L., \& Schmidt, L. (2005), "Self is Never Neutral: Why Economic Agents Behave Irrationally," Journal of Behavioral Finance, Vol. 6, Issue1, 2005, pp. 27-37.

15. Hare, Paul G. and Fofie, Felicia Owusu (2009), "Investment Behavior in a Difficult Institutional Environment", Journal of consumer Marketing, Vol 18, Issue 1, pp. 7-9.

16. Hossein Panahian, Mojgan, Safa, Mohammd Reza Panahian (2011), "Study of the Investors Attitude towards Financial Information Transparency on Explaining the Investment behavior in Tehran Stock Exchange", American Journal of Scientific Research, Vol. 2, Issue 8, pp. 87-99.

17. Jagongo, Ambrose and Mutswenje, Vincent S. (2014), “A Survey of the Factors Influencing Investments Decisions: The Case of Individual Investors at the NSE", International Journal of Humanities and Social Sciences, Vol. 4, Issue 4, pp. 92-103.

18. Jain, Dhiraj and Jain, Parul (2012), "Savings and Investment Pattern of School Teachers - A Study with Reference to Udaipur District, Rajasthan", International Journal of Research in Commerce, Economics \& Management, Vol. 2, Issue 6, pp. 119-127.

19. Jayaraj, S. (2013). The Factor Model for Determining the Individual Investment behaviour in India, IOSR Journal of Economics and Finance, 1(4), 21-32.

20. Kousalya P R and Gurusamy P (2012), Women Investorse Perception towards Investments, International Journal of Scientific Research, Vol. 1, Issue 6, pp. 80-81.

21. Mak, Mark KY and Lp WH (2017), "An Exploratory Study of Investment Behavior of Investors", International Journal of Engineering Business Management, Vol. 9, pp. $1-12$.

22. Meditinos, D, I., Sevic, Z., \& Theriou, N, G. (2007), "Investors' behavior in the Athens Stock Exchange", Studies in Economics and Finance, Vol. 24, Issue 2, 2007, pp. 32-50.

23. Mehru K.D (2004), Problems of Mutual Funds in India, Finance India, Vol.18, Issue 1, pp. 220- 224.

24. Murithi, S. Suriva, Narayanan, B. and Arivazagan, M. (2012), "Investors Behavior in Various Investment Avenues- A Study", IJMT, Vol. 2, Issue 7, pp. 2-17.
25. $\mathrm{Ng}$ and $\mathrm{Wu}$ (2005), "Factors influencing Individual investor Behavior", Financial Analysts Journal, Vol. 50, Issue 4, pp. 63-68.

26. Nosfinger and Richard (2002), Individual Investments Behavior, McGraw-Hill, New York.

27. Palanivelu, V.R. and Chandrakumar, K. (2013), "A Study on Preferred Investment Avenues among Salaried Peoples with Reference to NamakkalTaluk, Tamil Nadu, India", International Conference on Business, Economics, and Accounting, pp. 25-32.

28. Phan, Khoa Cuong and Zhou, Jian (2014), "Factors Influencing Individual Investor Behavior: An Empirical Study of the Vietnamese Stock Market", American Journal of Business and Management, Vol. 3, Issue 2, pp. 77-94.

29. Rehman K. Ur and Ahmed Imran hunjra (2012),'Factors Affecting the Investment Decision Making of Equity Fund Managers", Wulfenia Journal, Vol. 19, Issue 10, Oct 2012, pp. 1-25.

30. Sireesha, P. Bhanu and Laxmi, Shree (2013). Impact of Demographics on Select Investment Avenues: A Case Study of Twin Cities of Hyderabad and Secunderabad, India", International Journal of Marketing, Financial Services \& Management Research, Vol. 2, Issue 6, pp. 4755 .

31. Sultana, Syed Tabassum and Pardhasaradhi, S. (2012), "An Empirical Analysis of Factors influencing Indian Individual Equity Investors' Decision Making and Behavior", European Journal of Business and Management, Vol. 4, Issue 18, pp. 50-61.

32. Viviane Y. Naimy (2008), Equity Mutual Funds versus Market Performance: Illusion or Reality?", The Business Review, Vol 11, Issue 1, pp. 71-75.

33. Virani, Varsha, (2013), "Saving and Investment Pattern of School Teachers - A Study with Reference to Rajkot City, Gujarat", Abhinav Journal, Vol. 2, Issue 4, pp. 13-27.

34. Walia, N and Kiran R (2009), "An analysis of investor's risk perception towards Mutual Funds services", International Journal of Business and Management, Vol. 4, Issue 5, pp. 106. 